\title{
A book review: \\ Patryk Wawrzyński, Mit kulturowy jak czynnik kształtujący stosunki międzynarodowe, Toruń: Wydawnictwo MADO, 2011,pp. 170
}

\section{by Dagmara Ogrodowska}

Understanding cultural patterns and meaning of symbols, that show academics from George H. Mead, through Ruth Benedict, to Clifford Geertz, enable the cognition of human behavior and disquisition on its social importance. Commonness and universality of the cultural studies prove that the Humanities' center of gravity moved from describing the natural and material to explaining the cultural and inter-subjective.

However, this new focus has been smoothly adapted only in cultural anthropology and partially in sociology. Such disciplines as economy, jurisprudence, and political science still have not opened their front doors to the cultural approach, and even if it has become more common to revolve around identities, mythologies, narrations, and symbols, the most influential debates conduct about institutions, interests and material conditions of the social and political processes. The temporary break in this wall, made by Samuel P. Huntington's "Clash of Civilizations" has already been filled, defending these disciplines from interpretative and focused on ideas new methodologies.

Although, Huntington's break has been filled, the new construction is not so durable and tight as it was before his iconoclastic work. The exhibit of this lack of endurance is a book by Patryk Wawrzyński ["The Cultural Myth as a Shaping Factor of International Relations"]. The book shows a possibility of the application of cultural studies for political science's requirements; Wawrzyński attempts to introduce a focus on culture and identities methodology of international relations' research, simultaneously engaging in polemics with both leading IR paradigms: structural realism and neoliberalism. To establish his conception he went far from the political science [traditionally related to economics and law studies] and directly referred to an output of cultural anthropology, philosophy of culture, sociology and social psychology. Instead of boring Huntington's break, he decided to knock at the front door of political science with his own arrangement of cultural studies. And, it is justifiable to state that, Wawrzyński pursues his goals in an absorbing, considered, and somehow flashing way.

The title of the book suitably foreshadows its contents; indeed it is a work on the shaping of international relations by mythical narrations and symbolic communication. But not only. At once it is a book about constructing an identity in contemporary societies and international community, under- 
standing the international system as a space of the discourse of ideas, and to a high degree - about a story-telling in politics. For the author, that all seems to be indispensable for answering the main research dilemma: how cultural mythologies are able to reshape the construction of international relations and constitute society.

Already in the introduction Wawrzyński explains his interest in the influence of cultural mythology, sharing his hope that this approach may spread political researches towards investigations of constructing states' identities, developing convictions or expectations, and socialshared knowledge; and then, after this shift, may restore the possibility of peering at international relations as a space of vivid interactions that constitute social reality, instead of the mainstream describing the international system as a chessboard for Powers, regardless if it is a zero - or non-zero-sum game. The goal of Wawrzyński's work is by itself presented as crucial and innovative, while the subject of studies recognized as wrongly ignored by political scientists.

In fact, achievements of political science in the field of myth-based knowledge are not magnificent or even marginal, both for the discipline and for the Humanities en masse. As Wawrzyński noticed his book is one of the first polishlanguage works that emphasize the importance of symbolic communication's phenomena as factors in international relations. At the same time, the book perfectly correspond with changes that haveranged - since the 1990s - political science in the United States.

Wawrzyński does not conceal the great influence of Alexander Wendt's "The Social Theory of International Relations", that in the introduction calls the main inspiration of his research. As a matter of fact Wawrzyński's work is very similar to Wendt's one. Wendt work derives from the George H. Mead's symbolic interactionism, equally Wawrzyński exploits the Mircea Eliade's history of religion and the theory of hierophany. Both of them set sail from political science [especially international studies] and seek other solutions to their dilemmas among scientific achievements of Humanities.

That is not the end of the similarities between the American academic and his followers: both represent the social constructivist approach and both are far from a postmodern radicalism. Refuting fallacies of structural realist and neoliberal paradigms both have revolved around underlining the importance of culture, identities and social-shared knowledge, however they have not undermined the first rank of structural theorizing. Wawrzyński and Wendt are divided by an attitude to the relationship between theoretical and empirical studies: in the reviewed book Wawrzyński, side by side, has established the theoretical and epistemological model and shortly afterward has presented a case study based on his own method. As he himself notices every theory needs an empirical verification to show future prospects for researches. Unlike Wendt Wawrzyński has not 
restricted himself to just theorizing, and this course of action ought to be considered as the author's virtue.

The book has been divided into four chapters, proceeded by an introduction and enclosed by a conclusion, and a bibliography. The entirety takes up 170 pages published in a convenient format, that makes the reading comfortable and pleasant.

The first chapter, titled "The culture, the nation, the identity - the space of functioning of myths", take up the description of main social phenomena, that constitute the way of understanding the world and social constructions. Explaining inter-dependence between the culture, and the nation as a communitarian form of organization, and the identity as a culture-nation conjunction Wawrzyński has presented the model how cultural essences may shape social reality. Even thought this chapter has a character of theoretical and empirical achievements review, he has tried to authenticate identity studies as an important challenge for political science.

The second chapter, titled "The Cultural Myth", as it is predictable, answer questions about the construction, social functions and the presence of mythologies in contemporary societies and cultures. Using Ernst Cassirer's, Claude LeviStrauss', Leszek Kołakowski’s, Bronisław Malinowski's, and particularly previously mentioned Mircea Eliade's scientific accomplishments Wawrzyński has proved that mythical narrations are still present in the contemporary world, and like primordial societies are one of the main sources of social-shared knowledge. Summarizing, Wawrzyński has stated the Myth's emotional charge makes it eternal as a way of story-telling and as universal as a key to understand human's behavior.

The third chapter, titled "The Culture and the International Community", is an interesting and quality attempt to adapt anthropological and sociological approaches, presented in the first two parts of his work, in the field of political science's interest. Wawrzyński has firstly answered how he understands and processes the constituting international relations, based on the soft-constructivist ontology and creatively using Wendt's paradigm. Then he presented the model of inter-dependance between the Culture, the Nation, and the State [paraphrasing the title of the classic Kenneth Waltz's work in an engaging way] and has solved his main scientific dilemma of this book, answering how the Myth shapes international relations and how cultural mythologies constitute the structure of the International System and the meaning of Its customs and rules.

The fourth chapter, titled "The Interpretative Mechanism of the Cultural Myth's Role", shows the fundamental difference between Wawrzyński and his mentor Wendt. If the American academic to confirm his conclusions limits himself to some thought experiments, Wawrzyński has supported his theoretical argument by an advanced case study; concerning the Georgian-Russian military conflict in South Ossetia in August 2008 he has presented how the influence of cultural mythologies on international relations 
may be tested in practice. Using the Waltz's analysis' levels concept Wawrzyński has described myth-based processes and the social distribution of knowledge during the war. Even if sometimes interpretative methodologies have been criticized as speculative, Wawrzyński's one deserves to be considered by political scientists.

Crucial meaning for the importance of reviewed work has an extension of bibliographical sources; Wawrzyński has decided to refer to cultural anthropology, philosophy of culture and sociology and adapted other discipline's and achievements into political science. Probably, he is one of the few that has attempted to interpret Cassirer's, Eliade's, Kołakowski's, Malinowski’s, Levi-Strauss' or Wojciech
Burszta’s and Antonina Kłoskowska’s concepts to satisfy the research needs of political science. And itself it is praiseworthy. But it is even more commendable, because his intellectual ordeal yields satisfying and inspiring results.

Summing up, the Patryk Wawrzyński's book merits recommendation; in short it can be described as instructive, interesting, and a well-written monograph from the borderland of sciences. Even if the first chapter seems to be too much a review of different concepts and definitions, it is still a valuable theoretical introduction to subsequent studies. Time spent on the lecture of this book will not be lost, quite the contrary it will be a good choice, both for academics and students.

\section{A book review: \\ Luciano Canfora, Andrea Giardina, Chiara Frugoni, Alessandro Barbero, Alberto Mario Banti, Emilio Gentile, Andrea Graziosi, Vittorio Vidotto, Giovanni Sabbatucci, Andrea Riccardi, Michelle Perrot, I Volti Del Potere, Roma-Bari: Editori Laterza, 2010, pp. 318}

by Agnieszka Latosińska

The book I Volti Del Potere (Eng. The Faces of Power) is a collective work consisting of eleven chapters. The authors in an interesting way present the political fates and changes made by the great heroes of history, as well as the pros and cons of their governments, the stigma of which is often felt to this day.
In the opinion of the author of the reviewed book, the most interesting is chapter VI dedicated to Benito Mussolini and Fascism.

There is a complicated complexity in the relationship between Mussolini and Fascism. These relations started a new system of governance in Italy after 1922. 